\title{
Integration host factor is required for the activation of developmentally regulated genes in Caulobacter
}

\author{
James W. Gober and Lucille Shapiro' \\ Department of Developmental Biology, Stanford University School of Medicine, Stanford, California 94305-5427 USA
}

\begin{abstract}
Several temporally controlled flagellar genes in Caulobacter crescentus require a $\sigma^{54}$ promoter and upstream sites for transcription activation. We demonstrate here that in some of these genes, an AT-rich region containing an integration host factor (IHF) consensus binding site lies between the activator and the promoter, and that this region binds IHF in vitro. Analysis of mutations in the IHF-binding region of the hook operon demonstrated that an intact IHF-binding site is necessary for transcription in vivo. An adjacent and divergent promoter also has an IHF consensus sequence that binds IHF. The IHF and enhancer sites are $3^{\prime}$ to the transcription start site in this promoter. We postulate that IHF mediates the formation of a higher order structure between the divergent promoter regions in a manner analogous to the nucleosome-like structure generated for $\lambda$-Escherichia coli DNA recombination and that this higher order structure modulates transcription.
\end{abstract}

[Key Words: Caulobacter; IHF; fla genes]

Received May 23, 1990; revised version accepted July 6, 1990.

Caulobacter crescentus forms morphologically distinct daughter cells at each cell division. Asymmetry is generated in the predivisional cell, resulting in a stalked cell and a motile, swarmer cell that contains a single polar flagellum. The best studied aspect of this simple developmental cycle is the temporal biogenesis of the flagellum. Genetic analysis has identified over 48 genes responsible for the formation of this structure (Ely et al. 1984; Ely and Ely 1989|. A large number of these genes are transcribed during a discrete period in the cell cycle (Ohta et al. 1985; Loewy et al. 1987; Minnich and Newton 1987; Kaplan et al. 1989/ and their expression is controlled by a trans-acting regulatory hierarchy (Champer et al. 1987; Newton et al. 1989; Xu et al. 1989). The positioning of the genes in the hierarchy reflects their order of transcription, which in turn reflects the order of assembly of their gene products into the flagellar structure. In addition to the modulation of the temporal control, the products of these genes are localized to one pole of the predivisional cell. In an effort to understand both the temporal and spatial control of gene expression we analyzed the factors that control the transcription of the divergent hook operons ( $f l b G$ and flaN) and two flagellin genes $(f \lg K$ and $f \lg L)$.

The Caulobacter genes $f 1 b G$, flgK, and $f l g L$ (Mullin et al. 1978) require $\sigma^{54}$-containing RNA polymerase for in vitro transcription (Ninfa et al. 1989). Site-directed mutagenesis (Mullin and Newton 1989) has revealed an ac-

${ }^{1}$ Corresponding author. tivator site in the $5^{\prime}$ region of $f l b G$, analogous to $\mathrm{NtrC}$ sites found upstream of the glutamine synthetase promoters of enteric bacteria (Hirschman et al. 1985; Reitzer and Magasanik 1986). The Caulobacter enhancer-like $f t r$ sequences are located $\sim 100 \mathrm{bp}$ from the start of transcription (Chen et al. 1986; Minnich and Newton 1987; Mullin and Newton 1989) and are required for transcription of $f l b G$ in vivo (Mullin and Newton 1989). Genetic evidence suggests that the regulation of transcription of $f l b G$ is under both positive and negative control and is likely to be a multicomponent process because mutations in at least six genes abolish transcription (Xu et al. 1989; Newton et al. 1989) The product of one of these genes is likely to encode the protein that binds to the ftr element. We have recently purified a $95-\mathrm{kD}$ protein, RF-1, that binds to this upstream region (J.W. Gober and L. Shapiro, unpubl.) This binding activity is under cell cycle control and thus contributes to the temporal transcription of $f l b G$ (J.W. Gober, H. Xu, A. Dingwall, and L. Shapiro, unpubl.).

We report here that an AT-rich region positioned between the $\sigma^{54}$ promoter and the upstream $f t r$ site of these flagellar genes functions as a binding site for the basic, sequence-specific DNA-binding protein from Escherichia coli called integration host factor (IHF) (Nash and Robertson 1981). Western blot analysis of C. crescentus protein extracts with $E$. coli anti-IHF antibody revealed the presence of two cross-reacting polypeptides of a molecular weight similar to $E$. coli IHF, suggesting that Caulobacter possesses a homolog to this protein. Site-di- 
rected mutagenesis of the $f l b G$ IHF-binding region suggests that IHF is essential for in vivo transcription of the $\mathrm{flbG}$ operon. IHF is a heterodimer with subunits of 10.5 and $9.5 \mathrm{kD}$ that are encoded by the $\operatorname{him} A$ and $\operatorname{him} D$ genes of E. coli (Nash and Robertson 1981; Nash et al. 1987). In E. coli, IHF forms a nucleosome-like structure that is required for integrase (Int)-mediated recombination of bacteriophage $\lambda$ DNA (for review, see Friedman 1988). We postulate that the flbG and the divergent flaN promoter regions, both of which bind IHF, form a similar higher order structure that contributes to the transient temporal activation of these genes. The known diversity of IHF functions suggests that it might be a component of a global regulatory network for the temporal and spatial control of gene expression in Caulobacter.

\section{Results}

IHF binds to the region upstream of three flagellar promoters

The promoter and upstream regulatory region of the hook operon $(f l b G)$ and two flagellin genes $(f l g K$ and $f l g L)$ have a similar architecture (Fig. 1). The GG and GC conserved dinucleotides found in all $\sigma^{54}$-requiring promoters (Kustu et al. 1989) are underlined. A ftr consensus sequence reported by Mullin and Newton (1989) 100 bp upstream of the transcription start site, is indicated. These promoters also possess an AT-rich region that lies between the $f t r$ and the $\sigma^{54}$ promoter. In each promoter, the region extends $\sim 40-50 \mathrm{bp}$ between -90 and $-35 \mathrm{bp}$ from the start of transcription. The AT content of this region is $58 \%$ in the $f 1 b G$ promoter and $62 \%$ and $70 \%$ in the $f l g K$ and $f l g L$ promoters, respectively. Stretches of AT sequence in a GC-rich (67\%) organism such as Caulobacter are rare. Examination of these sequences re- vealed that they all contain the consensus binding site for IHF (Table 1). Figure 1 shows that these potential IHF-binding sites (open boxes) can occur on both strands and in either orientation. $f l b G$ has two IHF consensus sequences located on the coding (a) and noncoding (b) strand. The $f l g K$ consensus sequence occurs on the coding strand and is oriented in the same direction as $f l b G$ sequence (a). The consensus sequence in the flgL promoter region is in the opposite orientation and is located on the noncoding strand.

To determine if IHF could interact with these consensus sequences, we assayed binding in vitro using purified IHF from $E$. coli. A uniquely end-labeled DNA fragment that contains the $f l b G$ promoter region $(-120$ to $-8 \mathrm{bp}$ from the transcription start site) was used as a probe for gel mobility-shift assays. Relatively low concentrations of IHF (5-25 nM) retarded the mobility of the $f l b G$ promoter fragment in a nondenaturing polyacrylamide gel (Fig. 2A). The flgK upstream region was also tested with a uniquely end-labeled 280-bp fragment as a probe in the binding assay (Fig. 2B). The migration of this probe was retarded by the same concentrations of IHF used for the $f l b G$ promoter region.

The sequences bound by IHF were determined by DNase I protection assays using the same -120 to -8 fragment of the $f l b G$ promoter (Fig. 3A). Purified IHF protected $38 \mathrm{bp}$, corresponding to sequences -38 to -76 bp from the $f 1 b G$ transcription start site. This is approximately the size of the region protected by a single heterodimer of IHF in the attP region of bacteriophage $\lambda$ DNA (Craig and Nash 1984). Similarly, IHF protected $37 \mathrm{bp}$ in the $f \lg K$ regulatory region (Fig. $3 \mathrm{~B}$ ), and a 4l-bp sequence in the AT-rich region between the ftr and the promoter of $f 1 g L$ (Fig. $3 \mathrm{C}$ ). In each case, the protected regions extended beyond the IHF consensus se-

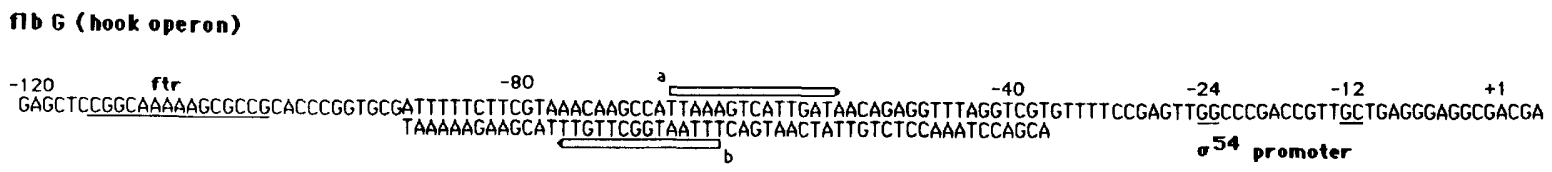

flg $\times(25$ Kd flagellin)

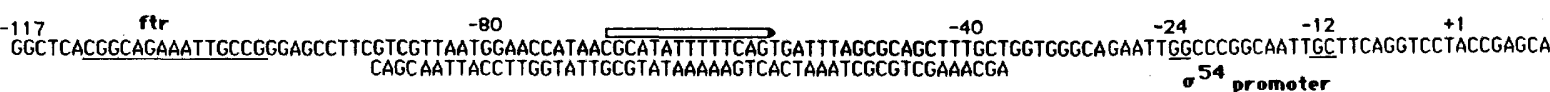

flg $L$ ( 27 Kd nagellin)

ftr
GCTGCCGCCCGGCGAATGTTGCATTCGCCGGGCGGTTTTGTTTTTGGCCGATAGATCCCAAAAAGATCAGCAAAAACAAATAGATATTITTCCTCGATTTTGGCGCGGGGCTGGCCCGCCGCTTGCGATGGTTCGCGCGGGCA
ACCGGCTATCTAGGGTTTTCTAGTCGTTTITGTTATCTATAAAAAGGGTAA

Figure 1. IHF sites in the upstream regulatory region of the flagellar genes $f l b G, f l g K$, and $f l g L$. The $5^{\prime}$ sequence of $f l b G$ and partial sequences of $f \operatorname{lgK}(-134$ to -90 and -40 to +7$)$ and $f \lg L(-140$ to -100 and -40 to +7$)$ are from Chen et al. (1986) and Minnich and Newton (1987). The 5' sequences of $f 1 g K$ and $f 1 g L$ were completed by the dideoxy sequencing method of Sanger et al. 1977 . The $\sigma^{54}$ promoter and the upstream $f t r$ activator sequence were identified by Mullin and Newton (1989). The $-12,-24$ conserved dinucleotide promoter sequences are underlined. Both strands of an AT-rich sequence between positions -38 and $-90 \mathrm{bp}$ from the start of transcription $(+1)$ are shown and the consensus sequence for an IHF binding site is indicated with an open box. Two IHF consensus sequences, shown as $a$ and $b$, are present in the $f l b G$ promoter region. 
Table 1. Comparison of IHF consensus sequences in Caulobacter flagellar promoters

\begin{tabular}{|c|c|}
\hline & -68 \\
\hline$f l b G_{1}$ & $\underline{\mathrm{T}}_{-65}^{\mathrm{T}} \mathrm{A} \underline{\mathrm{A}} \underline{\mathrm{A}} \mathrm{G} \mathrm{T} \mathrm{C} \underline{\mathrm{A}} \underline{\mathrm{T}} \underline{\mathrm{T}} \underline{\mathrm{G}} \underline{\mathrm{A}} \underline{-1}_{-78}^{\mathrm{T}}$ \\
\hline$f l b G_{2}$ & $\frac{\mathrm{T}}{-87} \mathrm{~T} \underline{\mathrm{T}} \underline{\mathrm{A}} \underline{\mathrm{A}} \mathrm{T} \mathrm{G} \mathrm{GC} \underline{\mathrm{T}} \underline{\mathrm{T}} \underline{\mathrm{G}} \frac{\mathrm{T}}{-64}$ \\
\hline$f \lg K$ & $\underset{-49}{\mathrm{G}} \mathrm{C}$ A $\underline{\mathrm{A}} \mathrm{T}$ T A C C $\underline{\mathrm{T}} \underline{\mathrm{T}} \underline{\mathrm{G}} \mathrm{G} \frac{\mathrm{T}}{-62}$ \\
\hline$f l g L$ & $\underset{+65}{\mathrm{~A}} \mathrm{~A} \underline{\mathrm{T}} \underline{\mathrm{A}} \mathrm{T} \mathrm{C} \mathrm{T} A \mathrm{~T} \underline{\mathrm{T}} \underline{\mathrm{G}} \mathrm{T} \underset{+52}{\mathrm{~T}}$ \\
\hline flaN & $\mathrm{G} C \underline{\mathrm{C}} \underline{\mathrm{A}} \underline{\mathrm{A}} \mathrm{G} C \mathrm{C} \mathrm{C} \underline{\mathrm{A}} \underline{\mathrm{T}} \underline{\mathrm{T}} \underline{\mathrm{G}} \underline{\mathrm{A}} \mathrm{A}$ \\
\hline att consensus & $\mathrm{T}:$ Py $\overline{\mathrm{A}}:::: \overline{\mathrm{Pu}} \overline{\mathrm{T}} \overline{\mathrm{G}}$ \\
\hline
\end{tabular}

quence as has been found for the attP sites in $\lambda$ DNA (Craig and Nash 1984).

\section{Effect of mutations in the IHF-protected region on binding affinity and in vivo transcription}

To determine if IHF-binding sequences are required for transcription, site-directed mutagenesis was performed on the $f l b G$ promoter region (Fig. 4). Mutagenized promoter regions were fused to a $\beta$-galactosidase transcription reporter gene and assayed for both the ability to bind IHF and $\beta$-galactosidase activity in vivo.

Because the precise contacts of IHF within the protected region are unknown, we first chose to introduce mutations that changed the consensus sequence. Using DNase I protection assays, we found that a mutation in the consensus sequence that changed AA to GG in 1302 was unable to bind IHF (Figs. 4 and 5F). IHF has been shown to interact primarily with adenine residues in the minor groove of the DNA helix (Yang and Nash 1989). We also changed the AT content of the region normally bound by IHF, but outside of the consensus sequence. Specifically, the adenine residues that lie 9 to $11 \mathrm{bp}$ from the right end of the $\lambda$ att $P$ core consensus are important for IHF binding (Yang and Nash 1989). The flbG IHFbinding site possesses an analogous set of adenine residues located on the noncoding strand, -47 to -45 from the transcriptional start (see Fig. 1). These nucleotides are within a short inverted repeat sequence at the boundaries of the IHF-protected region. Three of the five changes in mutant $\mathrm{HXr} 8$ alter the AT content from TTA to CGG. This results in a sequence (shown on the coding strand) that is no longer bound by IHF (Figs. 4 and 5B). A deletion of 11 bases in this region in mutant $\mathrm{HX} \Delta 8$, also abolished IHF binding (Figs. 4 and $5 \mathrm{C}$ ). This deletion restored two $\mathrm{T}$ residues mutagenized in $\mathrm{HXr} 8$, indicating that additional bases within this region are important for IHF binding. These mutations lie within a conserved 13-mer sequence that is found in the $5^{\prime}$ region of $f l b G$ and several other fla genes, including flbN and flaE (Kaplan et al. 1989) that do not contain an IHF core sequence. The binding of alternate proteins to this region may play a role in the differential control of fla gene expression. Although IHF was unable to bind the $f l b G \mathrm{mu}$ tant sequences at the concentrations (150-250 nM) tested in Figure 5, it could yield a partial, but specific DNase I footprint when tested at a concentration of 800 nM (data not shown). Gardner and Nash (1986) also found differences in binding affinity when mutated att $P$-binding sites were assayed for IHF binding.

Two mutations within the IHF-protected region do not affect the affinity of IHF for the binding site (Figs. 4 and $5 \mathrm{D}, \mathrm{E})$. One of these, a GG to TC change (HX6M) is in a region not expected to contact IHF, according to previous studies with the $\lambda$ attP sites (Yang and Nash 1989). The other mutation that failed to affect binding, $\mathrm{I} 3216$, is an alteration in the left arm of the inverted repeat sequence shown in Figure 4. Although an alteration in the right arm of the inverted repeat sequence in $\mathrm{HXr} 8$ had a strong effect on binding ability, an AA to CC change in 13216 had no effect. Because the mutated sequences in $\mathrm{I} 3216$ are located within consensus sequence b (shown in Fig. 1), these data indicate that IHF is utilizing the first consensus listed in Table 1 (sequence a) as its binding site in the $f l b G$ promoter.

Mutant $f l b G$ promoter regions fused to a promoterless $\beta$-galactosidase (lacZ) reporter gene were placed in a wild-type background and cultures were assayed for $\beta$ galactosidase activity (Fig. 4). The extent of $\beta$-galactosidase activity in these fusions is a direct reflection of the extent of transcription. Mutant promoters, $\operatorname{HXr} 8, \operatorname{HX} \Delta 8$, and $\mathrm{I} 302$, that had a significant reduction in binding affinity for IHF, also had five- to ninefold lower levels of $\beta$-galactosidase activity. The two mutant promoters that bound IHF with relatively high affinity retained about one-half the $\beta$-galactosidase activity observed with the

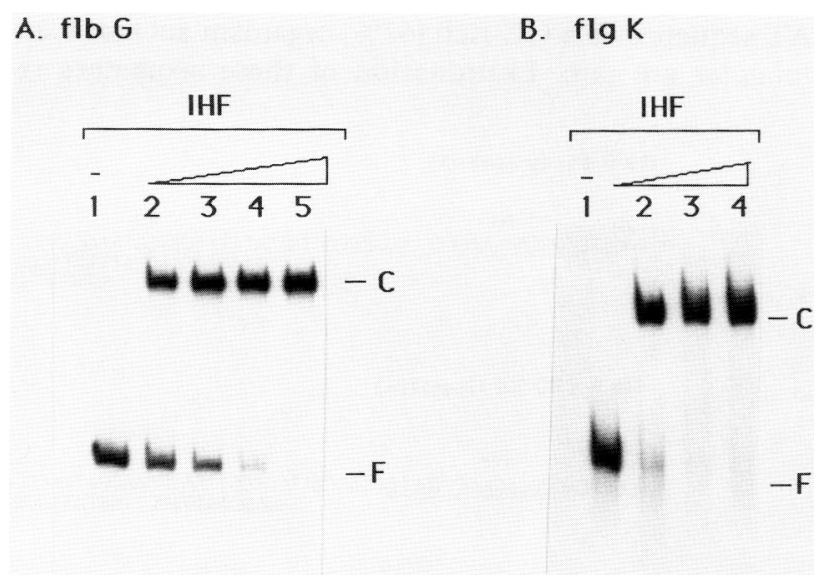

Figure 2. Gel mobility-shift assays with IHF and flagellar gene promoters. (A) flbG promoter. A 130-bp HindIII-EcoRI DNA fragment containing the $f l b G$ promoter region $(-120$ to -8$)$ flanked by 9 bp of pIcl9H polylinker, was end-labeled and purified as described in Experimental procedures. The labeled probe was incubated in either the absence or presence of purified $E$. coli IHF. (Lanes 1-5) Probe incubated with 0, 5, 10, 15, or $25 \mathrm{nM}$ IHF, respectively. (B) flgK promoter. An end-labeled 280-bp $N$ coI-EcoRI DNA fragment that contains the flg $K$ promoter region $(-145$ to +135$)$ was used as probe to test IHF binding. Binding conditions were as described in Experimental procedures. (Lanes 1-4) Probe incubated with 0, 10, 15, $25 \mathrm{nM}$ of IHF, respectively. 


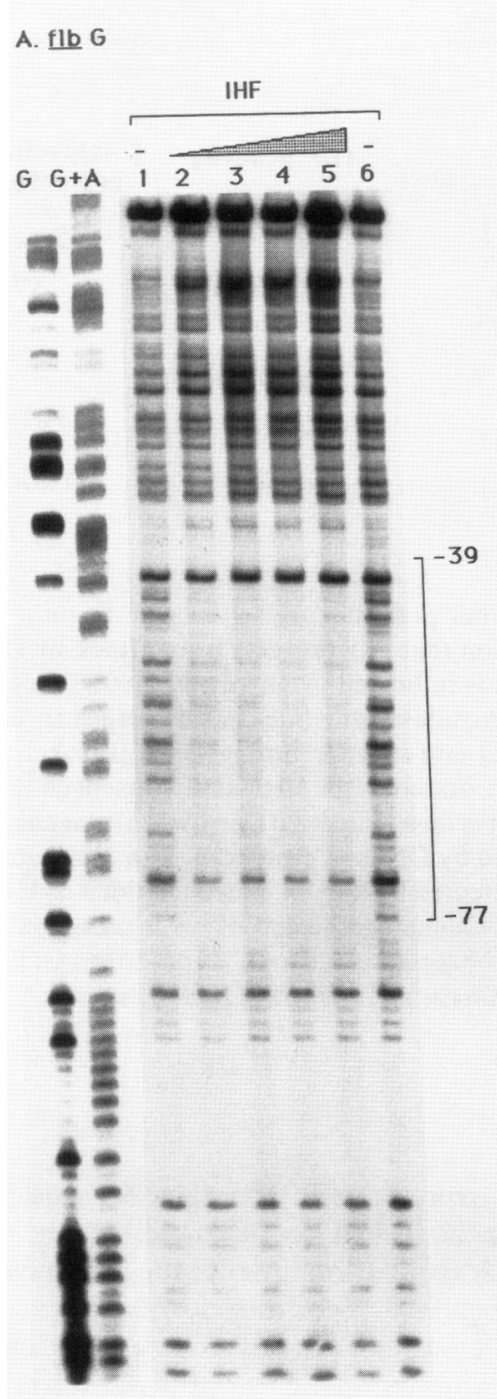

B. $f \lg K$

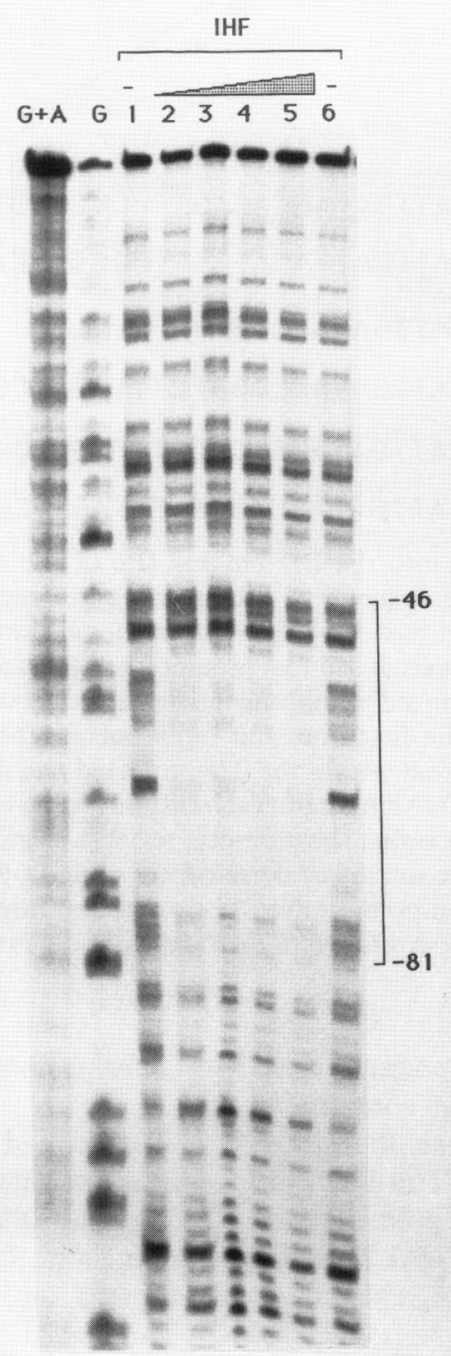

C. flg L

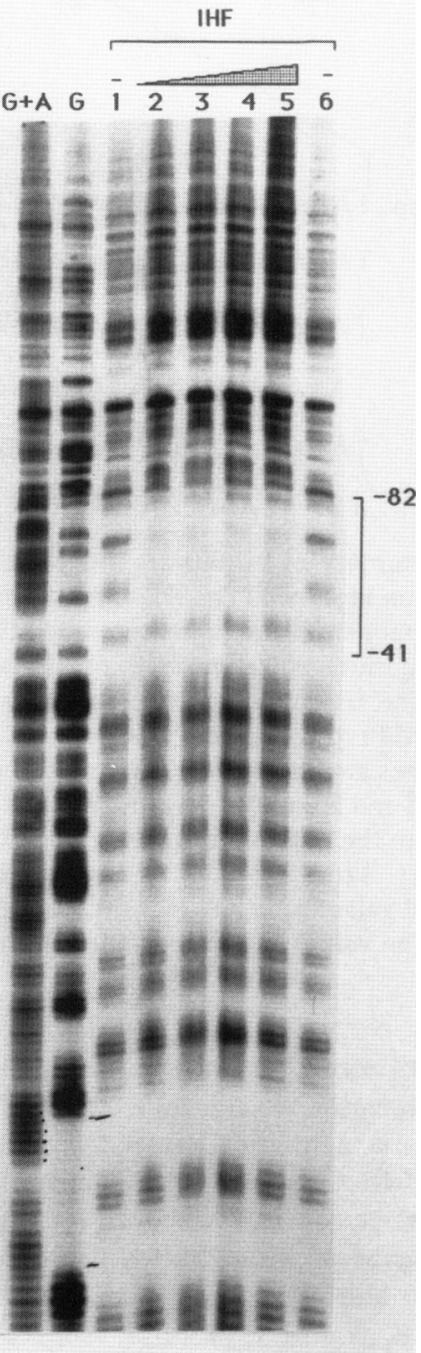

Figure 3. Identification of the IHF-protected region by DNase I footprinting assays. IHF binding protects the $f l b G$, $f l g K$, and $f l g L$ promoter regions from attack by DNase I. $(A)$ flbG promoter. An end-labeled 130-bp fragment HindIII-EcoRI containing flbG sequences from -120 to -8 was incubated in either the absence (lanes 1 and 6 ) or presence of IHF (50 nM, lane 2; $100 \mathrm{nM}$, lane 3; 150 $\mathrm{nM}$, lane 4; $200 \mathrm{nM}$, lane 5). The DNA-protein complexes were subjected to DNase I treatment, phenol/chloroform extracted, ethanol precipitated, and electrophoresed on an $8 \%$ acrylamide urea sequencing gel. The region protected from DNase I by IHF binding is shown as the open bracket to the right of the DNase I ladder. Numbers indicate the distance in bases from the start of transcription. Sequencing reactions are designated G and G + A (Maxam and Gilbert 1980). (B) flgK promoter. An end-labeled 280-bp NcoI-EcoRI fragment was used as a source of $f l g K$ promoter region DNA. The DNA fragment, containing $f l g K$ sequences from -145 to +135 , was incubated in either the absence (lanes 1 and 6) or presence of IHF (50 nM, lane 2; $100 \mathrm{nM}$, lane 3; $150 \mathrm{nM}$, lane 4; $200 \mathrm{nM}$, lane 5) and then treated as described in $(A) .(C)$ flg $L$ promoter. A 760-bp HindIII-EcoRI fragment, containing the $f l g L$ sequences from -650 to +110 , was incubated in either the absence (lanes 1 and 6 ) or presence (50 nM, lane 2; $100 \mathrm{nM}$ lane 3; $150 \mathrm{nM}$, lane 4; $200 \mathrm{nM}$, lane 5). The DNA-protein complexes were then treated as described in $A$.

wild-type construction. These results support the conclusion that the ability to bind IHF is required for transcription of the $f l b G$ promoter in vivo.

\section{flaN contains an IHF-binding site downstream of its promoter}

The divergent flaNQ operon is located directly $5^{\prime}$ to the flbG hook operon (Chen et al. 1986; Fig. 6). Newton and his co-workers have shown that flaN is transcribed from a $\sigma^{54}$ promoter (Mullin and Newton 1989; Ninfa et al. 1989). The ftr element that lies between the divergent $f l b G$ and flaN promoters is not required for flaN transcription (Mullin and Newton 1989; J.W. Gober and L. Shapiro, unpubl.). Deletion of the two ftr elements located $3^{\prime}$ to the transcriptional start of flaN, however, eliminates transcriptional activity (Mullin and Newton 1989 |. It is therefore likely that flaN transcription is ac- 


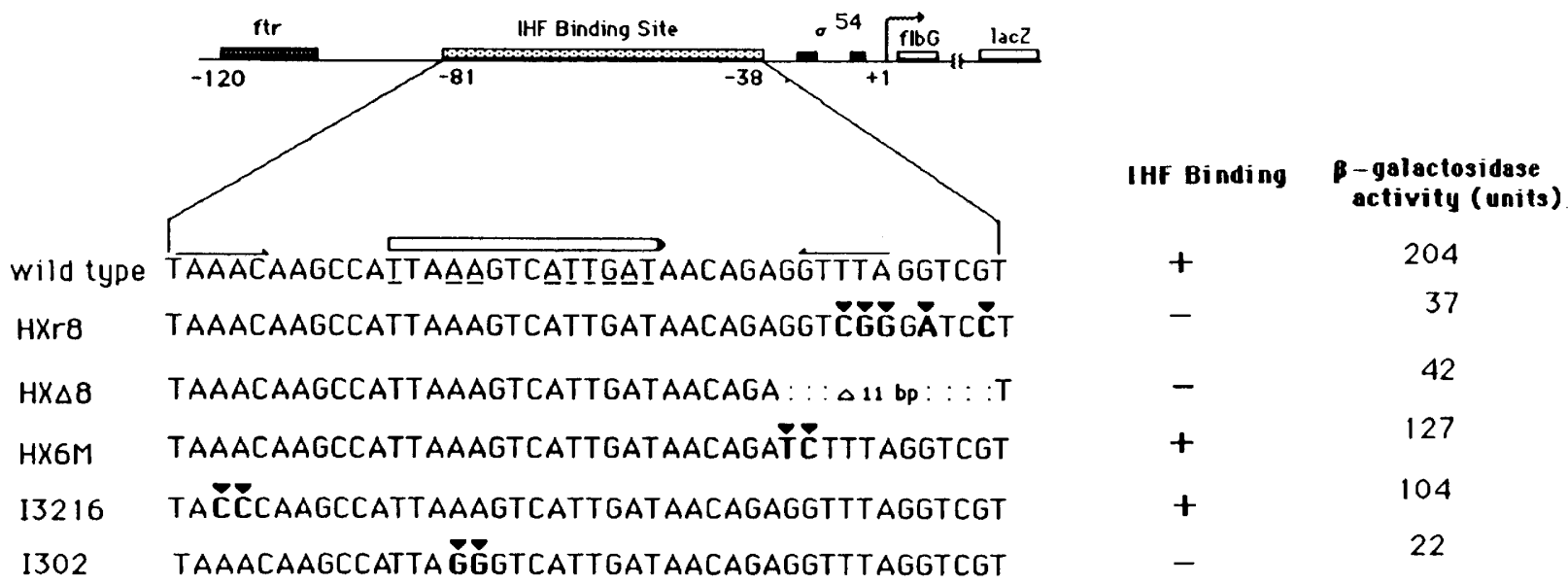

Figure 4. Summary of mutations introduced into the IHF-binding site of the $f l b G$ promoter. A schematic diagram of the $f l b G$ promoter region is shown. The IHF binding site, sequences -81 to -38 , is the region that IHF protects from attack by DNase I. The $\sigma^{54}$ promoter sequences are represented by filled boxes and the transcriptional start is indicated by an arrow. The wild-type promoter region and the mutagenized promoter regions were fused to a promoterless $\beta$-galactosidase gene (lacZ) as described in Experimental procedures. The IHF-binding site was mutagenized using oligonucleotide-directed site-specific mutagenesis (Kunkel and Roberts 1987). The wild-type sequence is shown on the first line, and the sequence that matches the attP IHF consensus site is boxed. Conserved bases are underlined. An inverted repeat within the IHF-protected region is designated with arrows. Mutagenized bases are shown in bold and are marked by arrowheads. IHF binding to each fusion was tested by DNase I protection assays shown in Fig. 5 . A plus sign $(+)$ in the IHF-binding column indicates that the promoter region was protected by IHF, at concentrations of 150 to $250 \mathrm{nM}$. A minus sign $(-)$ indicates that IHF was unable to bind at these concentrations. $\beta$-Galactosidase activity was measured by assaying $O$-nitrophenyl galactoside (ONPG) hydrolysis in permeabilized cells obtained from log-phase cultures, as described in Experimental procedures. The values shown represent the mean value of 6 to 10 separate determinations for each mutant promoter.

tivated by proteins that bind to these downstream sites. flaN also possesses an AT-rich region that contains an IHF consensus sequence similar to those found upstream of $f l b G$, flgK, and $f l g L$ (Table 1). The IHF consensus sequence for flaN lies between the promoter and the downstream $f t r$ sites, and thus is located $3^{\prime}$ to the transcription start site. Evidence that this sequence in fact functions as an IHF-binding site was demonstrated by the presence of a footprint in a DNase I protection assay (Fig. 7). When DNA from the flaN promoter region was incubated with IHF, a protected region of about 33 $\mathrm{bp},+24$ to +57 from the start of transcription, is observed (Fig. 7). Thus, two cis-acting elements normally found upstream of the $\sigma^{54}$ promoters, as in the $f l b G$, $f l g K$, and $f l g L$ promoter regions, are found downstream of the flaN promoter, supporting the contention that these cis-acting sites function as enhancers.

\section{Western blot analysis with anti-IHF antibody}

To date, IHF has not been characterized in any organism other than E. coli. We used Western blot analysis with antibody to $E$. coli IHF to determine whether Caulobacter possesses an IHF homolog. Two polypeptides in Caulobacter cell extracts were found to react with antiIHF antibody (Fig. 8). One band was the same molecular weight $(10.5 \mathrm{kD})$ as the $\alpha$-subunit of purified E. coli IHF, and the second band was slightly smaller than the $\beta$-subunit, suggesting that an IHF-like heterodimer is present in Caulobacter. An unidentified cross-reacting band was also present in the Caulobacter cell extracts.

\section{Discussion}

The timed expression of the flagellar components in Caulobacter is linked to other cell cycle events, including DNA replication, membrane biogenesis, and cell division. Localized flagellum formation is thus integrated into a number of global regulatory circuits that generate two distinct daughter cells at each cell division. In addition to responding to cell cycle cues, flagellar gene expression is also influenced by the assembly of the flagellum (Xu et al. 1989). Such complex control is thought to be accomplished at the level of transcription. An extensively studied flagellar promoter is that of the hook operon $(f l b G)$ (Chen et al. 1986). This promoter requires $\sigma^{54}$-containing RNA polymerase holoenzyme (Ninfa et al. 1989), in addition to sequences located at -100 bp from the transcription start for transcriptional activity. With analogy to the $n t r$ system, these upstream sequences have been termed ftr elements (Mullin and Newton 1989). Several trans-acting factors are apparently necessary for transcription of $f l b G$. The $f l b D$ gene, which is required for the transcription of the $f l b G$ operon, has been shown to encode a $52-\mathrm{kD}$ protein that is homologous to the transcriptional activators $N t r C$ and NifA (Ramakrishnan and Newton 1990). However, extracts of strains carrying mutations in $f l b D$ retain the ability to bind to the ftr element (J.W. Gober, H. Xu, A. Dingwall, and L. Shapiro, unpubl.). In addition, a 95-kD protein, RF-1, that binds to the ftr element, has been identified and purified (J.W. Gober and L. Shapiro, unpubl.). The binding activity is temporally regulated and 

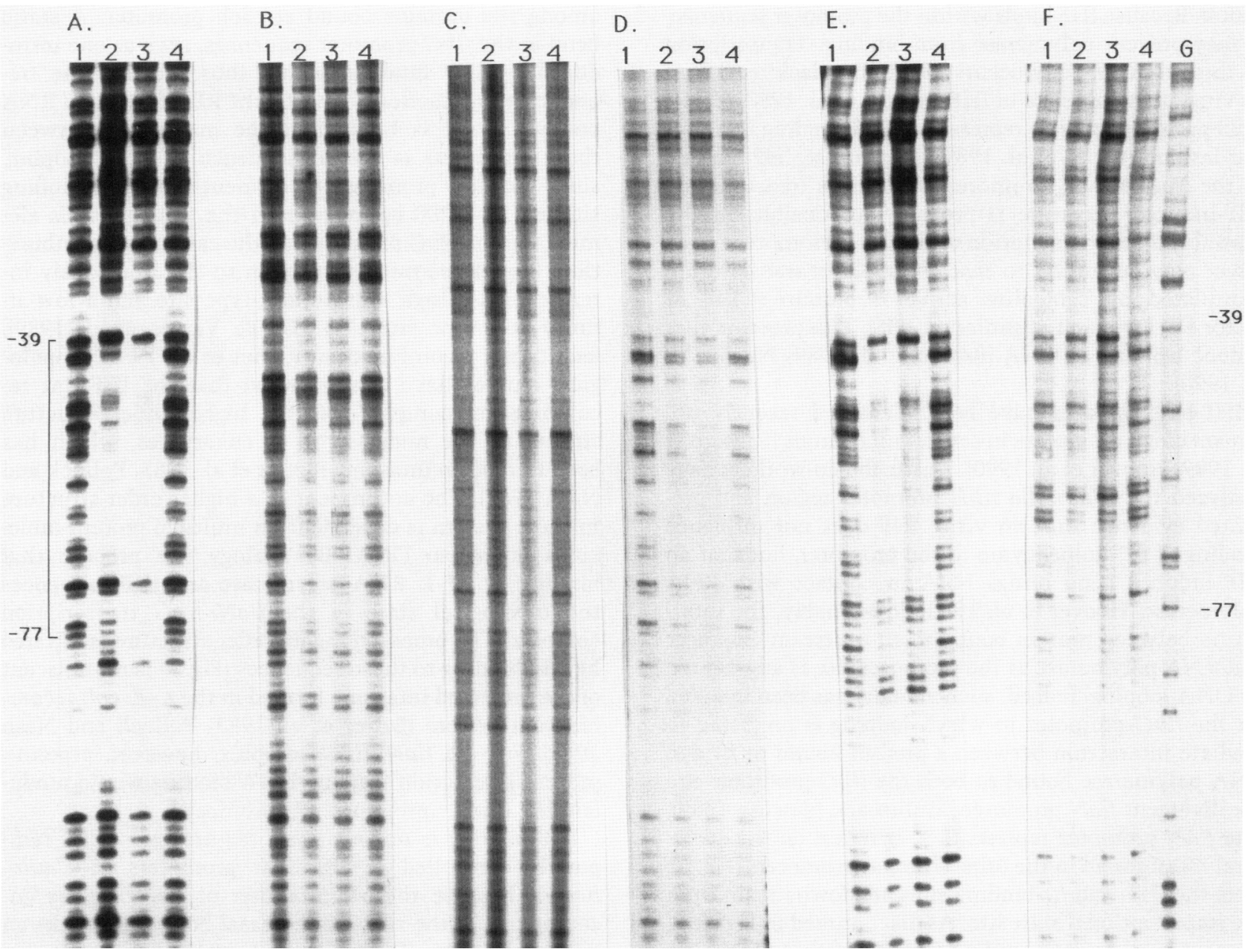

Figure 5. DNase I protection assays using IHF and mutnat $f l b G$ promoter regions. Each panel represents $f l b G$ wild-type $(A)$ or mutant promoter regions ( $\mathrm{HXr8}, B K ; \mathrm{HX} \Delta 8, C ; \mathrm{HX} 6 \mathrm{M}, D ; \mathrm{I} 216, E ; \mathrm{I} 302, F)$ incubated with (150 nM, lane 2; $250 \mathrm{nM}$, lane 3) or without (lanes 1 and 4$\}$ IHF. Probes were prepared as described in Experimental procedures. The open bracket on the left shows the extent of the region protected by IHF from DNase I attack in the wild-type flbG promoter. Numbers indicate the distance from the start of transcription. $\mathrm{G}$ lane is a sequencing reaction (Maxam and Gilbert 1980).

appears to be an important component in the timed transcriptional activation of the $f l b G$ promoter (J.W. Gober, H. Xu, A. Dingwall, and L. Shapiro, unpubl.). We have now identified an additional cis-acting element that is required for transcriptional activation of $f l b G$.

An AT-rich region that lies between the $\sigma^{54}$ promoter and the upstream $f t r$ region binds IHF. This IHF-binding site is important for transcription in vivo, since site-specific mutations that do not permit IHF binding fail to activate transcription. IHF has been implicated in both transposon and $\mathrm{Mu}$ transposition, site-specific recombination of bacteriophages $\phi 80$ and P22 (Leong et al. 1985), plasmid DNA replication (Stenzel et al. 1987), phage replication (Greenstein et al. 1988), and phase variation (Eisenstein et al. 1987). Elegant in vitro experiments by Nash and co-workers have demonstrated that IHF is required for the Int-mediated recombination between the $a t t B$ and $a t t P$ sites on the bacterial and lambda chromo- somes (Nash and Robertson 1981). Structural studies have shown that IHF binding introduces a bend in the DNA, estimated to be $\sim 140^{\circ} \mathrm{C}$ (Robertson and Nash 1987; Stenzel et al. 1987; Thompson and Landy 1988; Higgins et al. 1989; Kosturko et al. 1989). Exchanging an IHF-binding site with DNA sequences that possess natural curvature can relieve the IHF requirement for Intmediated recombination in vitro, thus demonstrating that the primary role of IHF is to organize higher order DNA structure (Goodman and Nash 1989).

The role of IHF in transcription is less well defined. IHF-binding sites have been identified in several bacterial $\sigma^{70}$ promoter regions. These include the E. coli ilvGMEDA operon, some bacteriophage $\mathrm{Mu}$ promoters, and the $\lambda \mathrm{P}_{\mathrm{L}}$ and pcin promoters (Pereira et al. 1988; van Rijn et al. 1988; Peacock et al. 1984; Griffo et al. 1989). In the case of the ilvGMEDA operon, IHF binding exerts a repressive effect on the transcription of the ilvGpl pro- 
moter. Because IHF binds within the promoter sequence, it may prevent polymerase from binding. Transcription of this promoter only occurs in mutants lacking IHF or in vitro in the absence of IHF (Periera et al. 1988). The $\lambda$ Pcin promoter may be repressed by IHF binding in a similar fashion (Griffo et al. 1989). In contrast, IHF binding to the $\mathrm{Mu}$ and $\lambda \mathrm{P}_{\mathrm{L}}$ promoters stimulates transcription. IHF-induced curvature is probably responsible for the stimulation of transcription of these $\sigma^{70}$ promoters. This effect may be similar to that observed for transcription stimulated by catabolite activator protein (CRP) or factor for inversion stimulation (FIS), two proteins that induce bending of DNA (Bracco et al. 1989; Nilsson et al. 1990).

IHF-binding sites have been identified recently upstream of $\sigma^{54}$ promoters in several nif operons (Santero et al. 1989; Hoover et al. 1990|. Kustu and co-workers have analyzed the Klebsiella nifH promoter region and presented evidence that, in vitro, IHF does not influence binding of $\sigma^{54}$ holoenzyme to the promoter, but that an IHF induced bend brings NifA in contact with RNA polymerase (Hoover et al. 1990). Presumably, the interaction between protein bound to an upstream enhancer and RNA polymerase at the promoter site is augmented by DNA looping. Indeed, such a model has been invoked for the $f l b G$ promoter in which looping is predicted to mediate interaction between a protein bound to $f t r$ and RNA polymerase bound to both the $f l b G$ promoter and the divergent flaN promoter (Mullin and Newton 1989). The flaN promoter represents a variation on the structural motif found in the other flagellar promoters (Fig. 6). Here the IHF- and $f t r$-binding sites are downstream from the transcriptional start site. As diagrammed in Figure 9, bends caused by IHF binding to each of these DNA sequences would increase the likelihood of interactions among the proteins bound at each promoter. A static bend in the $f l b G$ promoter sequences, such as one introduced by IHF binding, would thus increase the frequency of interactions between the RF-1 factor and RNA polymerase. It is likely that the interaction between these promoters is the consequence of DNA looping, since the flaN promoter, ftr elements, and IHF-binding site are all $\sim 200$ bp away from the analogous cis elements in the $f l b G$ promoter. In the case of $\lambda$ recombination, looping permits Int protein to simultaneously interact with a high affinity arm-type site and a low-affinity core-type site (Moitoso de Vargas et al. 1989), facilitating recombination (Richet et al. 1986). Topological studies have demonstrated that the IHF-Int recombination complex forms a higher order structure similar to the nucleosome of eukaryotes, which has been termed an intasome (Better et al. 1983; Pollock and Nash 1983). The attainment of a higher order structure in the $\lambda$ system is dependent on multiple protein molecules bound to DNA. By analogy, we propose that binding by RF-1, RNA polymerase and IHF influences the topological state of the flaN-flbG transcription complex. The proposed higher order structure facilitated by IHF binding to these sequences (Fig. 9) is reminiscent of the predicted intasome formed in the $\lambda-E$. coli recombination system (Better et al. 1983; Pollock and Nash 1983). For the flaN-flbG complex, however, proteinprotein interaction through DNA binding would modulate the transcription of these promoters.

IHF binding is not a general requirement of all temporally controlled $\sigma^{54}$ flagellar promoters in Caulobacter, because the $\sigma^{54}$ promoter of $f l b N$, a gene encoding one of the rings of the basal body gene, lacks an IHF-binding site (Dingwall et al. 1990). Some unrecognized feature of the upstream region or the promoter it-

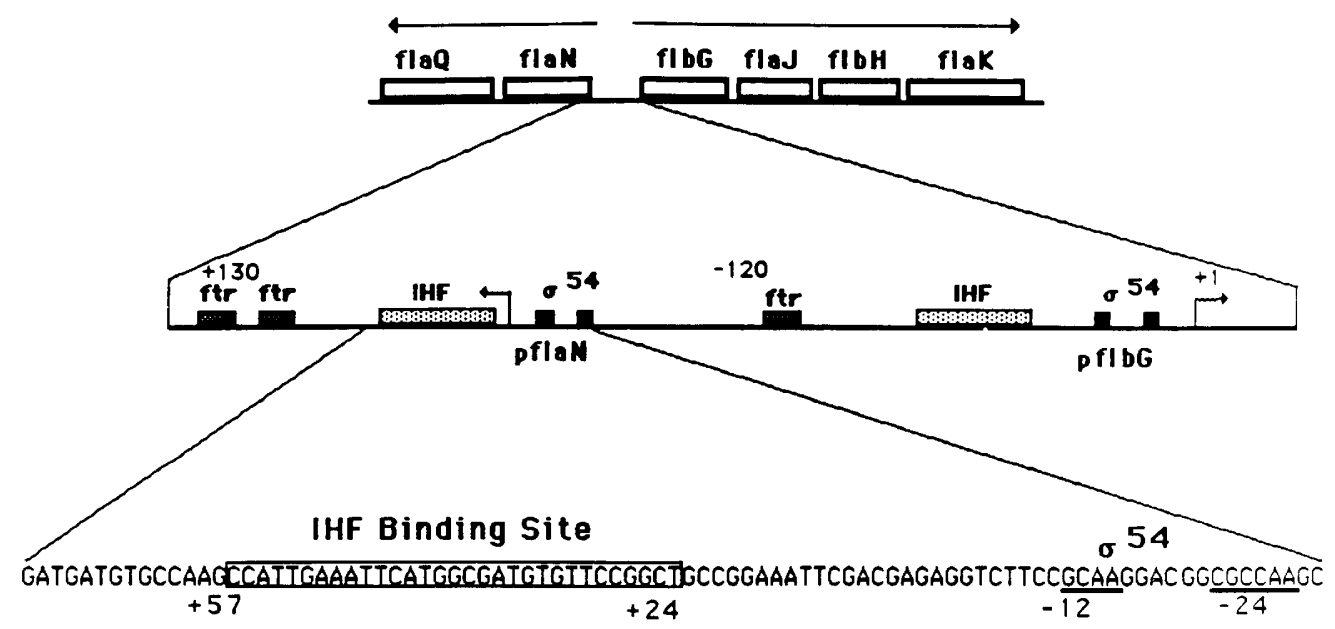

Figure 6. Genetic map of the flbG hook operon and the divergent flaNQ operon (Ohta et al. 1985; Chen et al. 1986). A schematic of the region between flaN and flbG is shown below the genetic map (Mullin and Newton 1989). The flaN $\sigma^{54}$ promoter is shown. The $f t r$ at $-120 \mathrm{bp}$ from the flbG transcription start is about $70 \mathrm{bp}$ upstream of the flaN promoter but is not required for transcription of $f l a N$ (Mullin and Newton 1989). Instead, sequences $3^{\prime}$ to the promoter, presumably the two ftr sequences at $+130 \mathrm{bp}$, are required for transcription (Mullin and Newton 1989). An IHF-binding site lies between these $\mathrm{ftr}$ sequences and the $\sigma^{54}$ promoter. Shown below is the sequence of the flaN promoter region from -20 to +70 (Mullin and Newton 1989). The IHF-binding site is boxed and lies between +24 and +57 bp from the start of transcription. 


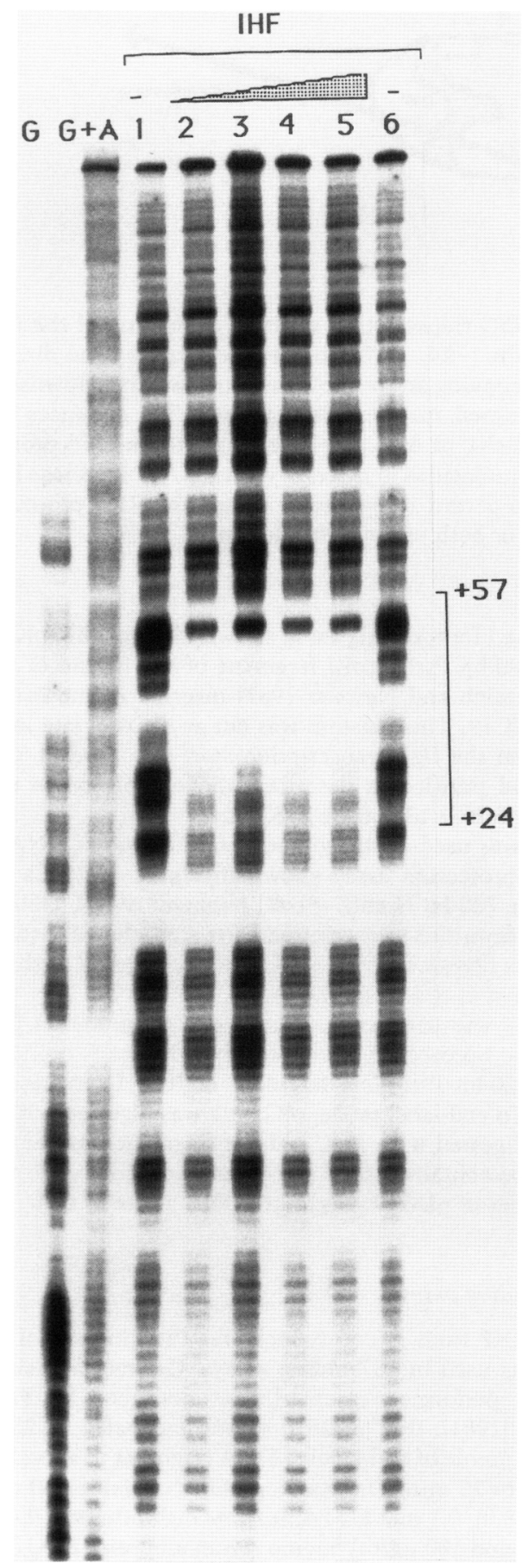

Figure 7. DNase I footprinting of the flaN promoter with IHF. A 429-bp PstI-EcoRI fragment ( -70 to +350$)$ with 9 bp of the polylinker was end-labeled and incubated with $50 \mathrm{nM}$ (lane 2); $100 \mathrm{nM}$ (lane 3); $150 \mathrm{nM}$ (lane 4); $200 \mathrm{nM}$ (lane 5); or without (lanes 1 and 6) IHF and treated as described in Experimental procedures. The protected region, +24 to +57 , is indicated. $G$ and $G+A$ represent the products of chemical sequencing reactions (Maxam and Gilbert 1980).

self dictates the IHF requirement of a $\sigma^{54}$ promoter. The $f l b N$ basal body gene is transcribed earlier than the $f 1 b G$ and flaN genes. Recent experiments with the Klebsiella pneumoniae nifH promoter indicate that the promoter sequences themselves are an important influence on whether IHF is required for transcriptional activation (Hoover et al. 1990). In this case, if the promoter strength is increased by mutations in the $\sigma^{54}$ recognition sequence, then IHF is no longer needed for open complex formation. The flbG hook promoter may be relatively weak, as evidenced by the low levels of $\beta$-galactosidase activity obtained with the transcription fusions (Fig. 4) and as reported by Newton et al. (1989). The temporal transcription of $f 1 b G$ might thus be controlled by the availability of IHF at unique times in the cell cycle. We have found recently that IHF is present in maximal amounts in predivisional cells at the time of $f l b G$ transcription (J.W. Gober, unpubl.). IHF is not present in the swarmer and stalked cell progeny. Because we know that a second trans-acting factor, RF-1, is also available only at the time when $f l b G$ transcription occurs normally (J.W. Gober, H. Xu, A. Dingwall, and L. Shapiro, unpubl.), the combination of these factors might fine tune the precise timing of gene expression.

Although the presence of IHF has not been demonstrated previously in nonenteric bacteria, anti-IHF antibody raised against purified $E$. coli IHF reacts with two proteins in Caulobacter that are similar in molecular weight to the subunits of the $E$. coli IHF heterodimer. We speculate that these two polypeptides represent the Caulobacter homolog of IHF. Extracts prepared from several strains that carry either Tn5 or deletion muta-

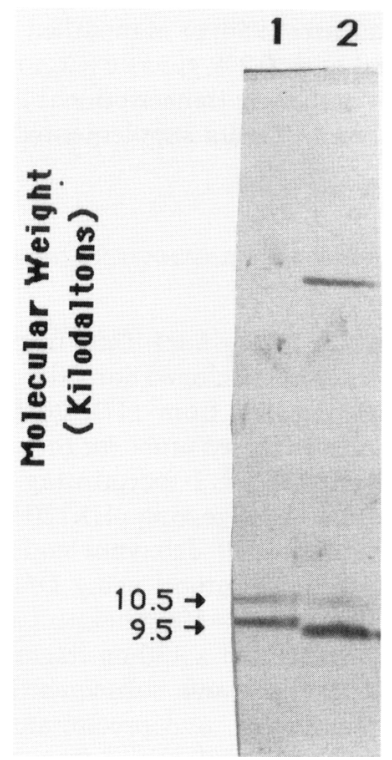

Figure 8. Western blot analysis with $E$. coli anti-IHF antibody. Crude cell extract (100 $\mu \mathrm{g}$ of protein) from Caulobacter (lane 2) was electrophoresed in a SDS-polyacrylamide gel as described in Experimental procedures. The separated proteins were electrophoretically transferred to nitrocellulose and the filter was incubated with a $1: 5000$ dilution of anti-E. coli IHF serum. Pure IHF (100 ng) was electrophoresed next to the Caulobacter cell extracts (lane 1). The indicated molecular weights $(10.5 \mathrm{kD}$ and $9.5 \mathrm{kD}$ ) are those reported for the $\alpha$ and $\beta$ subunits of the $E$. coli IHF, respectively. 


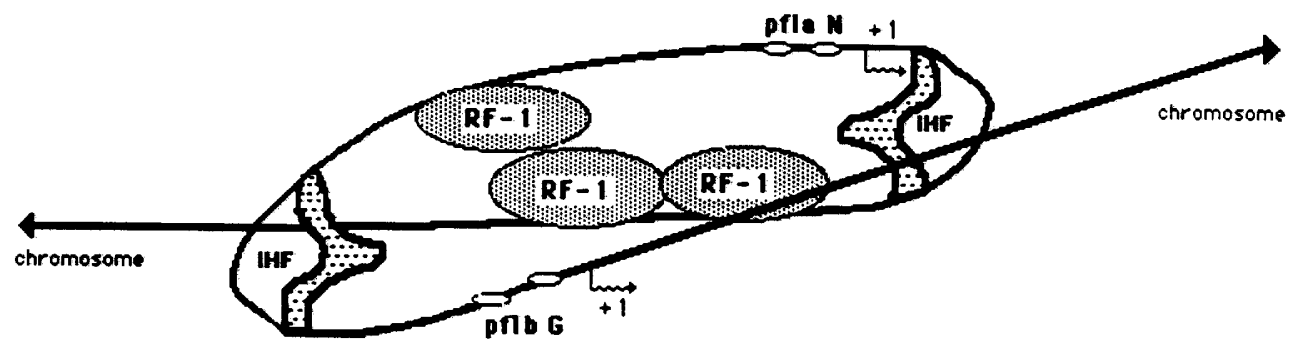

Figure 9. Diagram of a possible higher order structure adopted by the flaN-flbG transcription units. A schematic of the flaN and $f l b G$ promoter regions is shown. The small open boxes represent the site of the $-24,-12$ promoter sequences. The direction of transcription is indicated. RF-1 ovals represent the transcription factor, RF- 1 occupying an $f t r$ site. There are two sites downstream of the flaN transcription start and one site upstream of $f l b G$. Each RF-1, as diagrammed, may represent a dimer. The distances between protein binding sites are proportionally correct. In addition, the face of the helix of each RF- 1 binding site and $\sigma^{54}$ promoter is accurately depicted. IHF-induced bends in this region would enable bound RF-1 molecules to interact with RNA polymerase bound at the $\sigma^{54}$ promoter site. Furthermore, we propose that this structure would also permit interactions among the RF-1 proteins. This interaction, in turn, may influence the transcription initiation from either one or both of these promoters.

tions in flagellar regulatory genes (flaS, flaO, flbD, flaW, $f l b F$, and $f l b O)$ all possess these two polypeptides, indicating that IHF is not encoded by the currently known genes at the top of the flagellar regulatory hierarchy. Given the diversity of functions ascribed to IHF, it is reasonable to conclude that this protein has many roles other than flagellar biogenesis in Caulobacter.

\section{Experimental procedures}

Bacterial strains, plasmids, and growth conditions

Wild-type Caulobacter crescentus $(\mathrm{CB} 15 \mathrm{~N})$ was grown at $32^{\circ} \mathrm{C}$ in either PYE (Poindexter 1964) or in modified minimal M2 medium supplemented with $0.2 \%$ glucose (Contreras et al. 1978). C. crescentus cells harboring transcriptional fusions in Inc. Pl plasmids were grown in media supplemented with $1.5 \mu \mathrm{g} / \mathrm{ml}$ tetracycline.

\section{Preparation of flagellar gene promoter fragments for DNA binding assays}

A probe that contains a 116-bp SacI-DdeI fragment of the $f 1 b G$ upstream region (see Fig. 1) cloned into the SacI and EcoRV sites of pKic7 was prepared from $\mathrm{pHX120}$ (H. Xu and J.W. Gober, unpubl.). An end-labeled probe for the gel mobility-shift assay (Fig. 2) and the DNase I footprinting assay shown in Figure $3 \mathrm{~A}$, was prepared by digesting pHX120 with HindIII and labeling the end with $\left[\alpha^{-32} \mathrm{P}\right]$ deoxynucleotide triphosphates (Amersham, 3000-6000 Ci/mmol) using DNA polymerase I, Klenow fragment (Boehringer-Mannheim). Labeled DNA was then digested with EcoRI and a 130-bp fragment was isolated from a polyacrylamide gel and subsequently electroeluted, phenol/chloroform extracted, and precipitated with ethanol. This probe contains bases -120 to -8 from the transcription start of $f l b G$ plus 9 bases of pIc19H polylinker (Marsh et al. 1984 ) on either side. A larger flbG promoter fragment was used in the DNase I protection assays shown in Figure 5. The fragment contained positions -120 to +680 of the $f l b G$ gene plus $9 \mathrm{bp}$ of polylinker on the $5^{\prime}$ end and $18 \mathrm{bp}$ of polylinker on the $3^{\prime}$ side subcloned into pKic7 (pJG61). For probe preparation, pJG61 was digested with HindIII, labeled, digested with EcoRI, and purified as described above.

A probe prepared from pJG81 was used as the source of $f l g K$ promoter DNA for both the gel mobility-shift assay (Fig. 2) and the DNase I footprinting assay shown in Figure 3B. pJG8l contains a 580-bp PstI-EcoRI fragment of the $5^{\prime}$ end of the $f 7 g \mathrm{~K}$ gene (Minnich and Newton 1987) inserted in the PstI-EcoRI site of pUC19. This plasmid was cut at an NcoI site located at - 145 from the $f 1 g K$ transcription start site, labeled, cut with EcoRI, and purified as described above. This probe contains bases -145 to +135 of the $f l g K$ gene.

pJG72 was used as the source of flgL promoter DNA for the DNase I protection assay shown in Figure $3 \mathrm{C}$. This plasmid contains a 760-bp HindIII-EcoRI fragment of $f \lg L$ DNA $\mid-650$ to +110 from the transcription start site) cloned into pUC19. pIG72 was digested with EcoRI, labeled, digested with HindIII, and purified as described above.

pJG1901 was used as the source of flaN promoter DNA for the DNase I protection assay shown in Figure 7. pJG1901 contains a 420-bp PstI-SacI fragment of flaN DNA cloned into pUC19. To end-label probe, pJG1901 was digested with EcoRI, labeled, digested with PstI, and the fragment was gel purified. This probe contained flaN DNA from positions -70 to +350 plus 9 bases of pUC19 polylinker DNA at the $5^{\prime}$ end.

\section{DNA binding assays}

Purified IHF from E. coli (which was the kind gift of Howard Nash) was used in all binding assays. Gel mobility-shift analysis was performed essentially as described by Fried and Crothers (1981). IHF $(5-25 \mathrm{nM})$ was incubated at $25^{\circ} \mathrm{C}$ with 0.05-0.1 pmole of end-labeled DNA fragment in a total volume of $15 \mu \mathrm{l}$ for $20 \mathrm{~min}$. The reaction buffer contained $20 \mathrm{~mm}$ Tris$\mathrm{HCl}$ (pH 8.0), 0.1 mM EDTA, $0.1 \mathrm{~mm}$ dithiothreitol (DTT), 100 $\mathrm{mM} \mathrm{KCl}$, and $100 \mu \mathrm{g} / \mathrm{ml}$ bovine serum albumin (BSA) (Fisher et al. 1988). Complexes were electrophoresed in a nondenaturing polyacrylamide gel in $1 \times \mathrm{TBE}$ at $4^{\circ} \mathrm{C}$ (Maniatis et al. 1982).

DNase I footprinting assays (Galas and Schmitz 1978) were performed by incubating purified IHF $(50-200 \mathrm{nM})$ with labeled DNA fragment (0.01-0.05 pmole; $\left.0.5-1.0 \times 10^{5} \mathrm{cpm}\right)$ for 20 min at room temperature. The reaction mixture $(100 \mu l)$ contains $10 \mathrm{~mm}$ Tris (pH 7.5), $100 \mathrm{~mm} \mathrm{KCl}, 0.1 \mathrm{~mm} \mathrm{DTT}, 10 \%$ glycerol, and $50 \mu \mathrm{g} / \mathrm{ml}$ BSA. After incubation, the samples were placed on ice and mixed with an equal volume of a reaction mixture containing $20 \mathrm{mM}$ Tris- $\mathrm{HCl}(\mathrm{pH} 7.5), 200 \mathrm{mM} \mathrm{KCl}, 0.2$ mM DTT, 20\% glycerol, $100 \mu \mathrm{g} / \mathrm{ml}$ BSA, $10 \mathrm{mM} \mathrm{CaCl}_{2}, 10 \mathrm{~mm}$ $\mathrm{MgCl}_{2}$, and 15 units of DNase I (Boehringer-Mannheim). Reactions were terminated after $90 \mathrm{sec}$ by the addition of $200 \mu \mathrm{l}$ of $0.6 \mathrm{M}$ ammonium acetate, $0.1 \mathrm{M}$ EDTA, and $20 \mu \mathrm{g} / \mathrm{ml}$ of 
sheared calf thymus DNA (Craig and Nash 1984). Samples were extracted with phenol/chloroform and ethanol precipitated. The pellets were washed twice with $70 \%$ ethanol, dried, and resuspended in $80 \%$ (vol/vol) formamide, $1 \times \mathrm{TBE}, 0.05 \%$ bromophenol blue, and $0.05 \%$ xylene cyanol FF. The samples were heated at $85^{\circ} \mathrm{C}$ for $5 \mathrm{~min}$ and electrophoresed in $8 \%$ acrylamide-urea sequencing gels in $1 \times$ TBE (Maniatis et al. 1982). Sequencing reactions $(G, G+A)$ were loaded simultaneously and performed as described by Maxam and Gilbert (1980).

\section{flbG promoter mutagenesis and construction of transcription reporter gene fusions}

The IHF-binding sequences within the $f l b G$ promoter were mutagenized using the oligonucleotide site-directed mutagenesis methods of Kunkel and Roberts (1987). Mutagenesis was performed on M13mp19 single strand DNA containing the $1.3-\mathrm{kb}$ PstI-XhoI of the flbG $5^{\prime}$ region (Ohta et al. 1985). Mutations $\mathrm{HXr} 8, \mathrm{HX} \Delta 8$, and XH6M were constructed by Hong Xu of this laboratory. All mutagenesis was confirmed by dideoxy DNA sequencing using a synthetic primer complementary to bases +40 to +59 of $f 1 b G$ (Sanger et al. 1977).

For construction of $l a c Z$ transcription fusions, the $805-b p$ SacI-XbaI fragment from the mutagenized M13mpl9 clones was subcloned into the SacI-XbaI sites of pUC18. The fusions were constructed by ligation of an EcoRI-PstI fragment from the pUC18 subclones into plasmid pRSZ3 (M.R.K. Alley, unpubl.), which contains a promoterless $l a c Z$ gene from $E$. coli in a wide host-range plasmid which is derived from pRK290 (Ditta et al. 1980). The transcription fusions were introduced into $C$. crescentus by mating with an $E$. coli donor. $\beta$-galactosidase activity was measured in mid-log phase cells $\left(\mathrm{OD}_{660}=0.5-0.9\right)$ grown in PYE. C. crescentus CB15N with plasmid-borne $f 1 b G-$ $L a c Z$ fusions were permeabilized by addition of $100 \mu$ l of chloroform to $1 \mathrm{ml}$ of reaction mixture. Cell suspensions were incubated at $30^{\circ} \mathrm{C}$ for $5 \mathrm{~min}$ before the addition of substrate. The assay and calculation of unit activity was performed as described by Miller (1972).

\section{Western blot analysis}

Western blot analysis was performed as described by Towbin et al. (1979). Anti-IHF sera, provided by H. Nash, was incubated with blotted proteins at a $1: 5000$ dilution. Antibody protein complexes were detected using a secondary antibody conjugated to alkaline phosphatase (Bio-Rad). Alkaline phosphatase activity was visualized using a commercially available detection system (Boehringer-Mannheim).

\section{Acknowledgments}

We thank Howard Nash for kindly providing IHF protein and antibody to IHF and Sydney Kustu for helpful discussions. We also thank Hong Xu for subcloned regions of the mutagenized C. crescentus hook operon. This investigation was supported by U.S. Public Health grant GM32506 from the National Institutes of Health and grant MV408 from the American Cancer Society. J.W.G. is a Helen Hay Whitney Fellow.

The publication costs of this article were defrayed in part by payment of page charges. This article must therefore be hereby marked "advertisement" in accordance with 18 USC section 1734 solely to indicate this fact.

\section{References}

Better, M., S. Wickner, J. Auerbach, and H. Echols. 1983. Role of the Xis protein of bacteriophage $\lambda$ in a specific reactive complex at the attR prophage attachment site. Cell 32: $161-168$.

Bracco, L., D. Kotlarz, A. Kolb, S, Diekmann, and U. Buc. 1989. Synthetic curved DNA sequences can act as transcriptional activators in Escherichia coli. EMBO J. 8: 4289-4296.

Champer, R., A. Dingwall, and L. Shapiro. 1987. Cascade regulation of Caulobacter flagellar and chemotaxis genes. J. Mol. Biol. 194: 71-80.

Chen, L.-S., D. Mullin, and A. Newton. 1986. Identification, nucleotide sequence and control of developmentally regulated promoters in the hook operon region of Caulobacter crescentus. Proc. Natl. Acad. Sci. 83: 2860-2864.

Craig, N.L. and H.A. Nash. 1984. E. coli integration host factor binds to specific sites in DNA. Cell 39: 707-716.

Contreras, I., L. Shapiro, and S. Henry. 1978. Membrane phospholipid composition of Caulobacter crescentus. I. Bacteriol. 135: 1130-1136.

Dingwall, A., J.W. Gober, and L. Shapiro. 1990. Identification of a Caulobacter basal body structural gene and a cis-acting site required for activation of transcription. I. Bacteriol. (in press).

Ditta, G., S. Stanfield, D. Corbin, and D.R. Helinski. 1980. Broad host range cloning system for gram-negative bacteria: Construction of a gene bank for Rhizobium meliloti. Proc. Natl. Acad. Sci. 77: 7347-7351.

Eisenstein, B.I., D.S. Sweet, V. Vaughan, and D.I. Friedman. 1987. Integration host factor is required for the DNA inversion that controls phase variation in Escherichia coli. Proc. Natl. Acad. Sci. 84: 6506-6510.

Ely, B. and T.W. Ely. 1989. Use of pulsed field gel electrophoresis and transposon mutagenesis to estimate the minimal number of genes required for motility in Caulobacter crescentus. Genetics 114: 717-730.

Ely, B., R.H. Croft, and C.J. Gerardot. 1984. Genetic mapping of genes required for motility in Caulobacter crecentus. Genetics 180: 523-532.

Fisher, R.F., T.T. Egelhoff, J.T. Mulligan, and S.R. Long. 1988. Specific binding of proteins from Rhizobium meliloti cellfree extracts containing NodD to DNA sequences upstream of inducible nodulation genes. Genes Dev. 2: 282-293.

Fried, M. and D.M. Crothers. 1981. Equilibria and kinetics of lac repressor-operator interactions by polyacrylamide gel electrophoresis. Nucleic Acids Res. 9: 6505-6525.

Friedman, D.I. 1988. Integration host factor: A protein for all reasons. Cell 55: 545-554.

Galas, D. and A. Schmitz. 1978. A simple method for the detection of protein-DNA binding specificity. Nucleic Acids Res. 5: 3157-3170.

Gardner, J.F. and H.A. Nash. 1986. Role of Escherichia coli IHF protein in lambda site-specific recombination: A mutational analysis of binding sites. I. Mol. Biol. 191: 181-189.

Goodman, S.D. and H.A. Nash. 1989. Functional replacement of a protein-induced bend in a DNA recombination site. $\mathrm{Na}$ ture 341: 251-254.

Greenstein, D., N.D. Zinder, and K. Horiuchi. 1988. Integration host factor interacts with the DNA replication enhancer of filamentous phage F1. Proc. Natl. Acad. Sci. 85: 6262-6266.

Griffo, G., A.B. Oppenheim, and M.E. Gottesman. 1989. Repression of the $\lambda$ pcin promoter by integrative host factor. $J$. Mol. Biol. 209: 55-64.

Higgins, N.P., D.A. Collier, M.W. Kilpatrick, and H.M. Krause. 1989. Supercoiling and integration host factor change the DNA conformation and alter the flow of convergent transcription in phage Mu. J. Biol. Chem. 264: 3035-3042.

Hirschman, J., P.-K. Wong, K. Sei, J. Keener, and S. Kustu. 1985. Products of nitrogen regulatory genes $n t r A$ and $n t r C$ of en- 
teric bacteria activate $g \ln A$ transcription in vitro: Evidence that the ntrA product is a $\sigma$ factor. Proc. Natl. Acad. Sci. 82: $7525-7529$.

Hoover, T.R., E. Santero, S. Porter, and S. Kustu. 1990. The integration host factor (IHF) stimulates interaction of RNA polymerase with NifA, the transcriptional activator for nitrogen fixation operons. Cell (in press).

Kaplan, J.B., A. Dingwall, R. Bryan, R. Champer, and L. Shapiro. 1989. Temporal regulation and overlap organization of two Caulobacter flagellar genes. J. Mol. Biol. 205: 71-83.

Kosturko, L.D., E. Daub, and H. Murialdo. 1989. The interaction of $E$. coli integration host factor and $\lambda$ cos DNA: Multiple complex formation and protein-induced bending. $\mathrm{Nu}$ cleic Acids Res. 17: 317-334.

Kunkel, T.A. and J.D. Roberts. 1987. Rapid and efficient sitespecific mutagenesis without phenotypic selection. Methods Enzymol. 154: 367-382.

Kustu, S., E. Santero, J. Keener, D. Popham, and D. Weiss. 1989. Expression of $\sigma^{54}$ (ntrA)-dependent genes is probably united by a common mechanism. Microbiol. Rev. 53: 367-376.

Leong, J.M., S. Nunes-Duby, C.F. Lesser, P. Youderian, M.M. Susskind, and A. Landy. 1985. The phi 80 and P22 attachment sites. Primary structure and interaction with Escherichia coli integration host factor. J. Biol. Chem. 260: 44684477.

Loewy, Z.G., R.A. Bryan, S.H. Reuter, and L. Shapiro. 1987. Control of synthesis and positioning of a Caulobacter crescentus flagellar protein. Genes Dev. 1: 626-635.

Maniatis, T., E. F. Fritsch, and J. Sambrook. 1982. Molecular cloning: A laboratory manual. Cold Spring Harbor Laboratory Press, Cold Spring Harbor, New York.

Marsh, J.L., M. Evfle, and J.G. Wykes. 1984. The pIC plasmid and phage vectors with versatile cloning sites for recombinant selection by insertional inactivation. Gene 32: 481485.

Maxam, A. and W. Gilbert. 1980. Sequencing end-labelled DNA with base-specific chemical cleavages. Methods Enzymol. 65: 499-560.

Miller, J.H. 1972. Assay of $\beta$-galactosidase. In Experiments in molecular genetics, pp. 352-355. Cold Spring Harbor Laboratory Press, Cold Spring Harbor, New York.

Minnich, S.A. and A. Newton. 1987. Promoter mapping and cell regulation of flagellin gene transcription in Caulobacter crescentus. Proc. Nat1. Acad. Sci. 84: 1142-1146.

Moitoso de Vargas, L., S. Kim, and A. Landy. 1989. DNA looping generated by DNA bending protein IHF and the two domains of lambda integrase. Science 244: 1457-1461.

Mullin D.A. and A. Newton. 1989. Ntr-like promoters and upstream regulatory sequence $f t r$ are required for transcription of a developmentally regulated Caulobacter crescentus flagellar gene. J. Bacteriol. 171: 3218-3227.

Mullin, D., S. Minnich, S. Chen, and A. Newton. 1987. A set of positively regulated flagellar gene promoters in Caulobacter crescentus with sequence homology to the nif gene promoters of Klebsiella pnenumoniae. I. Mol. Biol. 195: 939943.

Nash, H.A. and C.A. Robertson. 1981. Purification and properties of the Escherichia coli protein factor required for $\lambda$ integrative recombination. J. Biol. Chem. 256: 9246-9253.

Nash, H.A., C.A. Robertson, E. Flamm, R.A. Weisberg, and H.I. Miller. 1987. Overproduction of Escherichia coli integration host factor, a protein with nonidentical subunits. J. Bacteriol. 169: 4124-4127.

Newton, A., N. Ohta, G. Ramakrishnan, D. Mullin, and G. Raymond. 1989. Genetic switching in the flagellar gene hierarchy of Caulobacter requires negative as well as positive regulation of transcription. Proc. Natl. Acad. Sci. 86: 66516655.

Nilsson, L., A. Vanet, E. Vijgenboom, and L. Bosch. 1990. The role of FIS in trans activation of stable RNA operons of $E$. coli. EMBO I. 9: 727-734.

Ninfa, A.J., D.A. Mullin, G. Ramakrishnan, and A. Newton. 1989. Escherichia coli $\sigma^{54}$ RNA polymerase recognizes Caulobacter crescentus flbG and flaN flagellar gene promoters in vitro. I. Bacteriol. 171: 383-391.

Ohta, N., L.S. Chen, E. Swanson, and A. Newton. 1985. Transcriptional regulation of a periodically controlled flagellar gene operon in Caulobacter crescentus. I. Mol. Biol. 186: $107-115$.

Peacock, S., H. Weissbach, and H.A. Nash. 1984. In vitro regulation of phage $\lambda$ cII gene expression by Escherichia coli integration host factor. Proc. Natl. Acad. Sci. 81: 6009-6013.

Pereira, R.F., M.J. Ortuno, and R.P. Lawther. 1988. Binding of integration host factor (IHF) to the ilvGpl promoter of the ilv GMEDA operon of Escherichia coli K12. Nucleic Acids Res. 16: 5973-5989.

Poindexter, J.S. 1964. Biological properties and classification of the Caulobacter group. Bacteriol. Rev. 28: 231-295.

Pollock, T.J. and H.A. Nash. 1983. Knotting of DNA caused by genetic rearrangement. Evidence for a nucleosome-like structure in site-specific recombination of bacteriophage lambda. I. Mol. Biol. 170: 1-18.

Ramakrishnan, G. and A. Newton. 1990. FlbD of Caulobacter crescentus is a homologue of the $\operatorname{NtrC}\left(\mathrm{NR}_{1}\right)$ protein and activates $\sigma^{54}$-dependent flagellar gene promoters. Proc. Natl. Acad. Sci. 87: 2369-2373.

Reitzer, L.J. and B. Magasanik. 1986. Transcription of $g \ln A$ in $E$. coli is stimulated by activator bound to sites far from the promoter. Cell 45: 785-792.

Richet, E., P. Abcarian, and H.A. Nash. 1986. The interaction of recombination proteins with supercoiled DNA: defining the role of supercoiling in lambda integrative recombination. Cell 46: 1011-1021.

Robertson, C.A. and H.A. Nash. 1988. Bending of the bacteriophage lambda attachment site by Escherichia coli integration host factor. J. Biol. Chem. 263: 3554-3557.

Sanger, F., S. Nicklen, and A.R. Coulson. 1977. DNA sequencing with chain-terminating inhibitors. Proc. Natl. Acad. Sci. 74: 5463-5467.

Santero, E., T. Hoover, J. Keener, and S. Kustu. 1989. In vitro activity of the nitrogen fixation regulatory protein NIFA. Proc. Natl. Acad. Sci. 86: 7346-7350.

Stenzel, T.T., P. Patel, and D. Bastia. 1987. The integration host factor of $E$. coli binds to bent DNA at the origin of replication of the plasmid pSC101. Cell 49: 709-717.

Thompson, J.F. and A. Landy. 1988. Empirical estimation of protein-induced DNA bending angles: Applications to lambda site-specific recombination complexes. Nucleic Acids Res. 16: 9687-9705.

Towbin, H., T. Staehlin, and J. Gordon. 1979. Electrophoretic transfer of proteins from polyacrylamide gels to nitrocellulose sheets: Procedure and some applications. Proc. Natl. Acad. Sci. 76:4350-4354.

van Rijn, P.A., N. Goosen, and P. van de Putte. 1988. Integration host factor of Escherichia coli regulates early- and repressor transcription of bacteriophage $\mathrm{Mu}$ by two different mechanisms. Nucleic Acids Res. 16: 4595-4605.

Xu, H., A. Dingwall, and L. Shapiro. 1989. Negative transcriptional regulation in the Caulobacter flagellar hierarchy. Proc. Natl. Acad. Sci. 86: 6656-6660.

Yang, C.C. and H.A. Nash. 1989. The interaction of E. coli IHF protein with its specific binding sites. Cell 57: 869-880. 


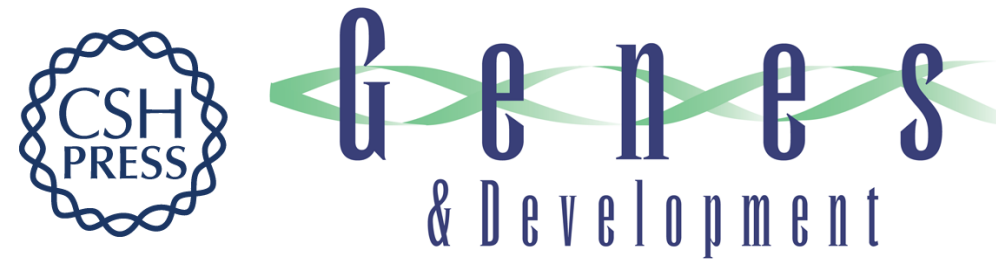

\section{Integration host factor is required for the activation of developmentally regulated genes in Caulobacter.}

J W Gober and L Shapiro

Genes Dev. 1990, 4:

Access the most recent version at doi:10.1101/gad.4.9.1494

References This article cites 54 articles, 26 of which can be accessed free at: http://genesdev.cshlp.org/content/4/9/1494.full.html\#ref-list-1

License

Email Alerting

Service

Receive free email alerts when new articles cite this article - sign up in the box at the top right corner of the article or click here.

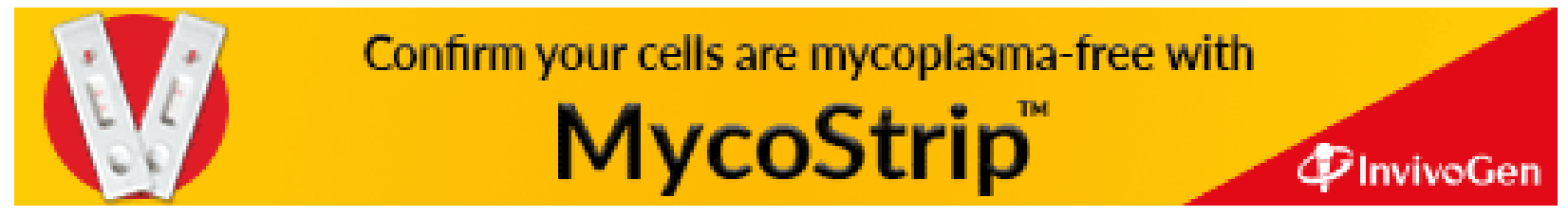

